\title{
NGO Management a Skill to Be Taught!
}

\author{
Dr. Alma Vögeli \\ Nehemiah Gateway University, Pogradec, Albania
}

MBA. Engjellushe Icka

Nehemiah Gateway University, Pogradec, Albania

\begin{abstract}
The aim of this article is to collect available information on NGOs in Albania and their requirements for educated and trained employees and volunteers with specific skills and capabilities that are in line with the investors' requirements concerning application, implementation, and reporting systems. Since 1991 with the process of democratization and under the motto "To make Albania like Europe" the first NGO started to flourish (Jorgoni, 2013) in the fresh post-communist Albania. Mainly the NGOs started their activity in Albania as branches or daughter organizations of the mother NGOs from European and USA countries. The mother NGOs shared experience and funds with but the Albanian reality and infrastructure was not prepared to digest and implement the information and knowledge offered. Albanian NGOs were the first institutions in Albania that smelled freedom and Europe. Being member of any NGO had a strong conceptual and emotional meaning as if being member of the big real world outside the cold communist epoch. The communist curtains (Churchill 1946) for 45 years destroyed private propriety and legal institutions together with the perception of the individuals for free life and the big world. Aiming shrinking of people's mind to fit the parameters of a communist red block full of black names and fake facts; generating the New Man only if the very nature of man can be changed to conform to the requirements of the new communist order (Alt and Alt 1964). Nowadays Albanian society shares social problems (drug, human rights etc.) with Western Europe; political problems with Asian and East Europe; and environmental problems with Central Europe and rest of the world.
\end{abstract}

Keywords: Non-Profit Organization, third sector, social marketing, voluntary behavior, CSO (civil social sector),

\section{Introduction}

"If I had known I was going to live this long, I would have taken better care of my health" (Forbes 1979).

If the Albanian society would have known the real importance and the role and impact of NGOs in its life they would have been much more careful since the moment a NGO is created and registered.

A Non-Governmental Organization (NGO) is a citizen-based association that operates independently of government, usually to deliver resources or serve some social or political purpose. (Whatls.com 2016)

The World Bank classifies NGOs as either operational NGOs, which are primarily concerned with development projects, or advocacy NGOs, which are primarily concerned with promoting a cause.

1991 - 1997 period is considered as a difficult transition in which the economic, politic and social life of Albania started to take shape according every western pattern available. During this period representation of NGOs are working in the main sectors of activity: democracy, Women, Social service/health, Business and environment" (Partners Albania NGO Assessment Report, 2002). During this first economical-social-political transition period, "chaos" is the brand name of everything and also NGOs although being supported by international institutions couldn't escape the reality. The first NGOs of the period 1991-1996 were some of the first to penetrate communities, facilitating discussion on taboo issues such as reproductive health, family planning, abortion and sex education as well as offering family planning service (Xhillari, et al. 2013). 
1997-2002 period is the second period of political-economical-social chaos increased somehow the number, funds and the variety of social issues covered by Albanian NGOs. (PA 2002). After 1997 the issue of trafficking everything illegally from drugs to women and children out of Albania increased the number of NGOs in human rights area.

2002-2013 is the third transition period for NGOs when NGOs consolidated their capacity and influenced more in the Albania society. (PA 2002)

Although the NGOs activity started since 1991, the 15 years of experience still face great problems:

Lack of management capabilities in the major number of NGOs, specially local ones

Lack of measurable performance

Lack of reporting systems and auditing competencies

Lack of responsibility to conclude what is started and is paid for.

All these reported problems come out of one big issue, lack of proper education and training for NGOs management.

\section{NGOs Role in a Society}

According Misra, Rajeeb (2008) were identified three major roles for voluntary organizations in a democracy:

a) Political role - In this capacity, NGOs are mechanisms through which people voice their concerns and make demands on the government for socio-political reforms.

b) Educational role - NGOs provide training to develop the skills of their members and to educate the public, especially the depressed sections of society, on their rights.

c) Watchdog role - NGOs serve to watch the government in its use of power and promote accountability to the public.

d) Socio - economic booster role - The support of the NGO can start with the identification of the need, its presence through the entire process until the very important step of the revision and auditing.

\section{Methods and Methodology}

The secondary data is collected from articles on NGOs; reports of international organism that observe the NGOs performance and impact in Albania; INSTAT Albania on the availability and the share and importance of NGOs in the economy, employability and funds; HEls curricula and academic programs.

\section{Results}

"There are about 500 to 600 local NGOs registered, about half of these are fully engaged in on-going activities" USAID Country Index (1999)

TASCO Albania Office (2011) reports that there are 2231 registered associations, 311 foundations, 522 centers in Albania. Only 450 NGOs or CSO are active all over Albania.

NGO number is increased in years. Tirana Court of First Instance, registers CSOs and maintains the CSO register, there were 6,855 CSOs in Albania at the end of 2014 (USAID 2014).

According Vimala Parthasarathy (2012), "The growth of the NGO sector consisting of non-government organizations engaged in social welfare and development activities has been accelerated in recent years by several factors: 1) increase in fund availability for social causes, 2) positive public perception of the capacity of the voluntary sector to address social concerns and increasing awareness of the limitations of state and public agencies to reach out effectively to sections of society needing transformation."

\section{Ngo typical structure}

In a typical NGO structure, (see Fig 1) one realizes the complexity and its clear separated functions. Simple structure of NGOs leads to the obvious lack of necessary elements, usually the General Director or the Leader who is the one to obtain 
the funds (project planning and application) but not necessarily able to manage the processes of organization, managing the unplanned situations, and reallocation of funds as consequence.

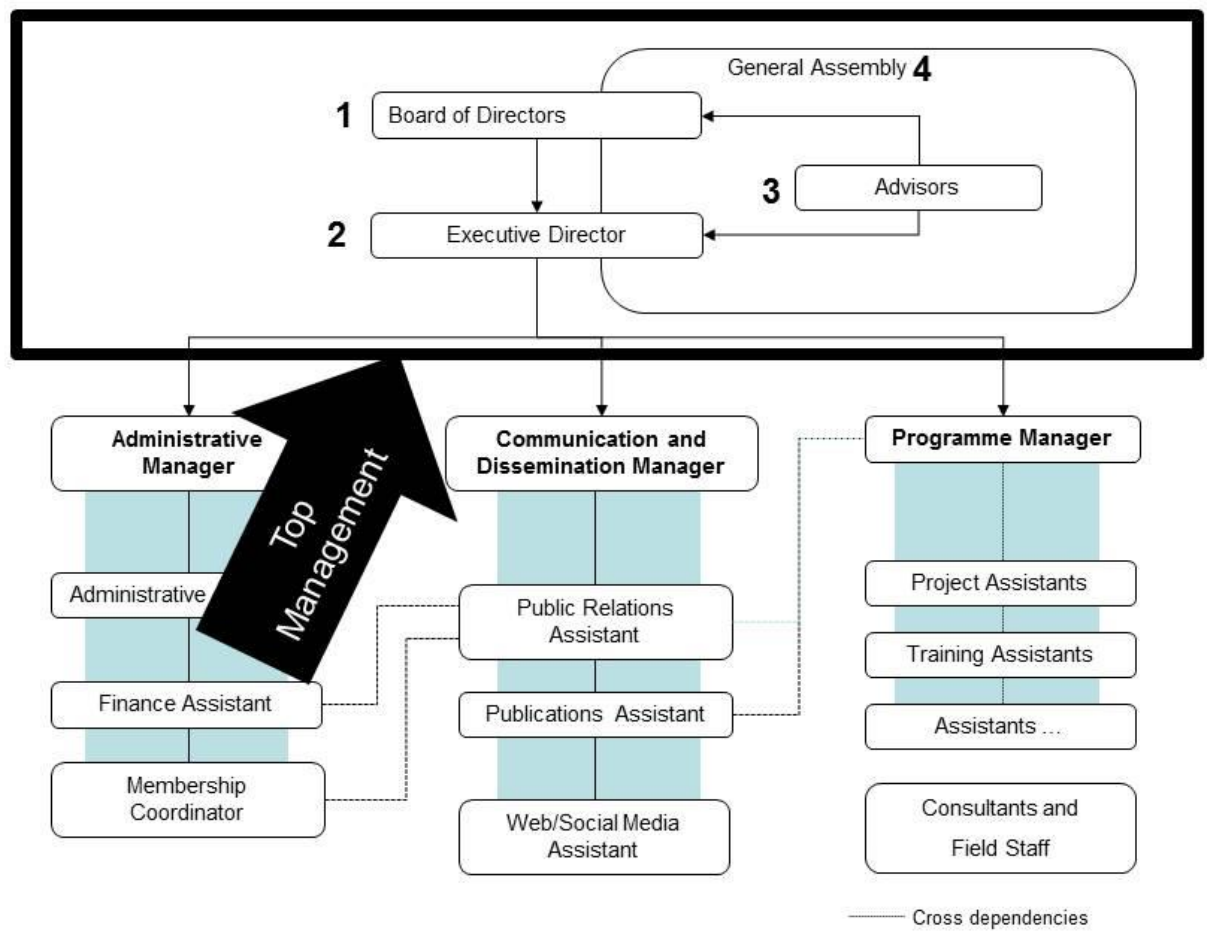

Fig. 1. Organizational structure of a typical NGO after Hari Srinivas (2015)

\section{Legal framework for NGOs in Albania}

The legal framework regarding the NGOs in Albania is regulated by:

Albanian Constitution 1991

Civic code of Republic of Albania

Law 8750 date 29.07.1994

Amended by Law 8791 date 03.05 .2001

Law 8788 date 07.05 .2001 "On non-profit organizations"

Law 8789 date 07.05 .2001 "On non-for profit organizations registration"

Law 8781 date 03.05.2001 "On some amendments and changes in Law 8750 date 29.07.1994 Civic Code of Republic of Albania" 


\section{Tax exemption}

The main authority responsible for registering the nonprofit organizations is the Tirana District Court. The nonprofit organizations have various exemptions on their taxes:

the revenue realized by donations or membership dues are not taxed,

the income tax is not applicable on donations, and

various customs obligations have granted relieves and exemptions.

Supported by and according Albanian Customs Code (1999), the Article 199 "Relief from Customs Duty" point k, "goods for charitable, philanthropic, or assistance purposes for charitable organizations, religious institutions, public entities, as well as budget funded state entities; amended by art. 17 of law no. 8473 dated 14.4.1999,

\section{Top 6 findings from the report of Partners Albania (2013):}

No.1. Financial reporting and accounting rules are not effective and appropriate for CSOs. (PA 2013)

No. 2. There is confusion in the legal framework regarding the exemption of the grants from tax, leading to different interpretation in practice. (PA 2013)

No. 3. The Public Benefit Status is regulated through a decision of Council of Ministers and does include a limited number of working areas of CSOs (NGO). (PA 2013)

No. 4. Public funding is available only for the past three years through state agency Civil Society Support Agency. It does not support institutional development and co-financing of EU projects. (PA 2013)

No. 5. There are no national strategic documents dealing with the state and CSO (NGO) relationship associated with lack of adequate structures and mechanisms with a mandate to facilitate cooperation between the state and CSO. (PA 2013)

No. 6. In practice CSOs are not able to obtain contracts in competition with other service providers due to lack of clear rules and procedures and lack of capacities from the government institutions on contracting out CSOs. (PA 2013)

Need for training is observed in Albanian NGOs and reported by UNDP Albania "Capacity needs and training assessment of Roma/Egyptian NGOs, (March 2013)". The report describes in general the situation of the NGOs in Albania and specifically the situation of minority communities like Roma and Egyptian. The Roma/Egyptian NGOs are not necessarily managed and operated by respective minority members, therefor the lack of training/education is not an issue related to these specific institutions but as a part of the todays reality.

"Civil society in Albania is reportedly weak, mainly concentrated in urban areas and dependent on external funding" (Jorgoni 2013). The improvements are slow and deficiencies are still high regarding the specifics of the NGOs even after 22 years of experience in this field. "Most NGOs characterize EU application procedures as highly complex, and feel that in general, they are not prepared to comply with EU requirements related to project management and reporting" (Jorgoni 2013).

"The third sector should increase its capacity for advocacy and public relations, networking and development of partnership with the Government and the private sector. Financial and management capacities also need to be strengthened to ensure the future sustainability of the third sector" (Xhillari, et. al. 2013).

\section{NGOs Human Resources}

It is a fact that NGO Management faculties do not exist in any of the Albanian universities (public or private) MAS (2016), but as long as the third sector is consolidated as a market it needs its own capital.

\section{Sustainability}

USAID report (2014) says: "CSO sustainability in Albania improved in 2014, with advances in organizational capacity, advocacy, and infrastructure. CSOs have increased their internal organizational capacities, constituency building mechanisms, and advocacy efforts, and the government increasingly recognizes the contribution of CSOs in major national 
reforms and policy-making processes. The legal environment, financial viability, service provision, and public image, on the other hand, have stagnated."

\section{NGOs Statistical Data}

According the Agency for the Support of Civil Society (2015) registered NGOs in Albania are concentrated to the most populated regions. If you rank them the highest number is exercising their activity in Tirana 313 or $69 \%$, the second comes Korca with 27 or $6 \%$ and then Shkodra $5 \%$ and Vlora $4 \%$. The rest of the regions have a very small part of the NGOs funds.

Referring the fig 2, regarding the legal form of Enterprises (INSTAT 2014), among the registered enterprises the NGOs share only $2 \%$ of the entrepreneurship activity in Albania.

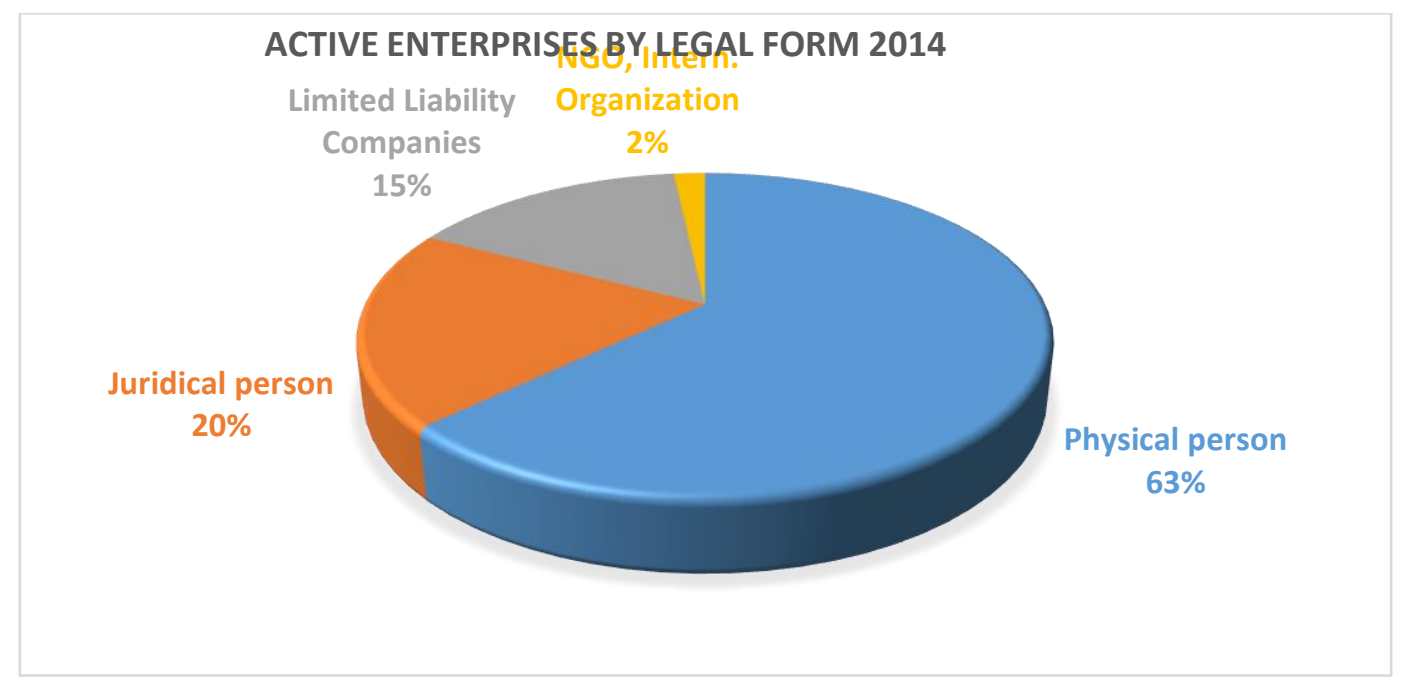

Fig. 2. Registered businesses in Albania 2014 (INSTAT Albania)

Registered trend of NGOs during the period 1991 - 2008 shows that most of them is registered since the beginning of the democratization process but the real boom appears to be after the period of the 1997 crisis about 49\%, (PA 2007).

According Peter Frumkin (2005), the voluntary sector or community sector is the duty of social activity undertaken by organizations that are not for-profit and non-governmental, this sector is also called the third sector, in contrast to the public sector and the private sector. The strong impact of the third factor is to neutralize and diminish the outcome that generates the other two factors government and business. The awareness raising and gaining people is the key of success and the existentialist meaning of any NGO.

Election and policy watchdogs NGOs will continue to exercise their activity "to increase its capacity or advocacy and public relations, networking and development of partnership with government and private sector" (Xhillari, et. al. 2013)

\section{Training Availability for NGOs Staff Members in Albania.}

Xhillari et. al (2013) found that 1) Lack of NGO training and low volunteering rates have been identified as a key problem, and 2)There is frequently poor NGO knowledge of EU systems, they require a focused attention to the NGOs, establishment and operation.

The institution of Partners Albania offers NGOs training programs in the fields of: Cross Sector Training (PA 2015)

\section{Development of Training Capacities}

Youth Leadership

\section{Women Empowerment}


Cross Sector Training

Private Sector Training

Local Government Training

Training Topics for NPOs (non-profit)

Most of the Albanian NGOs miss the HRM development plans because of their high dependence on funding donors, the projects turnover and the size of the respective NGO. This makes the staff of the third sector very mobile.

\section{Promoting NGOs / Social Marketing}

Its a thousand times harder to do social marketing than to do package goods marketing, (Novelli 1979)

\section{Discussion}

As long as the third sector works mainly with the international funds and the most important part of them are daughters or branches of international NGOs, the understanding and then the application and implementation of the respective legislation, rules and regulations should be conform the investors or mother NGOs platforms. Specially the application and reporting forms.

Albania by means of being a candidate member of EU, and aspiring to be part of it within the next 10 years, leads to the exigency to capture the EU's education requirements. It is necessary that the process of finding the parallel lanes starts now because in the due moment of integration it will be very disappointing for the graduated generation.

It is the moment to fight for the stability of the NGOs staff. This should be an ongoing task of the NGOs, of the advisory institutions, of the auditory organisms of government and also a specific task of the educational institutions to prepare and offer curricula that fulfill the NGOs requirements.

Referring to the same intention of the above-mentioned reports on the situation of the NGOs in Albania, is necessary the preparation of a curricula specifically adapted for NGO management within a business administration faculty arranged according the European models and Bologna Card education standards.

The Albanian education system is still oriented theoretically and has a gap in the practical integration, that inhibits the quality performance achievement of NGO projects and thus the lifespan of the organization as such.

There is still a long way to improve the exemption of the NGOs activity from the customs taxes and duties.

\section{References}

[1] Alt, Herschel, and Alt, Edith (1964) - The New Soviet Man: His Upbringing and Character Development. New York: Bookman Associates, 1964. Print.

[2] Albanian Customs Code 1999 (Internet accessed 02.01.2016)

[3] Agency for the Support of Civil Society in Tirana http://www.amshc.gov.al/web/index-en.php

[4] Churchill (1946) - Sinews of Peace, Westminster College in Fulton, Missouri on March 5, 1946 ;Winston Churchill's Iron Curtain Speech

[5] Civil code of Republic of Albania 2012, (Internet accessed 02.01.2016) http://www.qbz.gov.al/botime/fletore_zyrtare/2012/PDF-2012/Kodi\%20Civil-2012.pdf

[6] EU CIVIL SOCIETY CONTACT GROUP

[7] http://www.act4europe.org/code/en/materials.asp?Page=223 (internet accessed 14.01.2016)

[8] Hari Srinivas (2015) - Organizational Structure of a Typical NGO, Hari Srinivas concept note series E104, march 2015, (web http://www.gdrc.org/ngo/org-chart.html\#footnotes) 
[9] Frumkin, Peter (2005). - "On being nonprofit : A conceptual and policy primer (1 ed.). Cambridge, Mass".: Harvard University Press. ISBN 0-674-01835-4.

[10] INSTAT Albania 2014, (Internet accessed 02.01.2016) http://www.instat.gov.al/al/themes/regjistri-statistikor-ind\%C3\%ABrmarrjeve.aspx

[11] INSTAT Albania 2015, http://www.instat.gov.al/al/themes/arsimi.aspx (Internet accessed 02.01.2016)

[12] USAID, "2014 CSO Sustainability Index for Central and Eastern Europe and Eurasia" https://www.usaid.gov/sites/default/files/documents/1863/CSOSI-Report-FINAL-7-2-15.pdf

[13] "Monitoring Matrix on Enabling Environment for Civil Society Development, Country Report for Albania 2013", Partners Albania http://www.partnersalbania.org/Albania_Country_Report.pdf

[14] Misra, Rajeeb, (2008) - "Voluntary Sector and Rural Development", Rawat Publications, Jaipur.

[15] MAS (2016) - Ministria e Arsimit dhe Sporteve, (Ministry of Education and Sports of Albania http://www.arsimi.gov.al/ ) (internet accessed 28.12.2016)

[16] Partners Albania, Center for Change and Conflict Management, Capacity Needs and Trainings Assessment of Roma/Egyptian NGOs, by Elira Jorgoni for UNDP Albania, march 2013.

[17] USAID Country Index (1999) - "Development of the non-profit sector"

[18] Partners Albania Center (2013) - Partners Albania Center for Change and Conflict Management report "Monitoring Matrix on Enabling Environment for Civil Society Development, Country Report for Albania (2013)

[19] Vimala Parthasarathy 2012, Social Marketing Strategies \& Traits of Successful NGOs - A Strategic Perspective

[20] William D. Novelli (1979), "Problems in Applying Conventional Marketing Wisdom to Social Marketing Programs." paper presented at American Marketing Association Workshop, "Exploring and Developing Government Marketing," Yale University.

[21] Whatls.com - (http://whatis.techtarget.com/definition/NGO-non-governmental-organization) (Internet accesses 23.12.2016)

[22] Xhillari et. al. (2013) Report of Euclid Network, "Third Sector Development in Albania: Challenges and Opportunities" (Lindita Xhillari, Ylli Cabri, Armand Frangu). http://euclidnetwork.eu/eu-funding-andpolicy/resources/doc_view/119-third-sector-development-in-albania 